\title{
75. On the Effect of Castration in the Silkworm, Bombyx mori $L$.
}

\author{
By Shintaro HaMaSAKI. \\ Zoological Institute, Faculty of Agriculture, Tokyo Imperial University.
}

(Comm. by C. Sasaki, M.I.A., June 13, 1932.)

With a view to determining the effect of castration on the silkworm, Bombyx mori L., the present investigation was undertaken at the suggestion of Dr. Ishiwata, making use of the following races: Ohao, Kasuriko (univoltine) and Showa, Shi $103 \times$ Nichi 110 (bivoltine). In experiments castration was practised mainly at the beginning of the fourth larval stage with satisfactory results. After cutting open the fifth abdominal segment the gonads were taken off with ease. The larvae thus operated on, though feeble and immotile for a while owing to bleeding, soon recover their vitality. So far as experiments go, the third and fifth stage larvae are not adequate, because of difficulty of operation in the former owing to the small size of the body as well as of impossibility of operation in the latter without severe bleeding owing to the large size of the gonads. During the course of experiments the larvae operated on were left untouched, being subject to the natural healing of the wound, and were bred in the same number and state as the control. The results obtained are summarised in the following.

\section{The duration of stages in the silkworm operated on.}

The silkworm larvae submitted to operation at the beginning of the fourth or the fifth stage retain the duration of the said and following stages much longer than the control, though this is not evident in the fifth stage of the larvae operated on at the preceding stage. This state of things can be seen from the results given in the following table. After all, castration results in the remarkable prolongation of the life duration of the moth, especially the female. The moth, in spite of the entire absence of the gonads, is of almost the same body-weight as the normal. In fact it provides with the con-

Here I deem it my duty to offer my hearty thanks to Dr. Ishiwata for valuable advice. My thanks are also due to Professor Kaburaki for criticism and advice. 


\begin{tabular}{|c|c|c|c|c|c|c|c|}
\hline \multirow{3}{*}{ Stage } & \multirow{3}{*}{$\begin{array}{l}\text { No. } \\
\text { of } \\
\text { lots }\end{array}$} & \multicolumn{4}{|c|}{ Duration of stages (time in hours) } & \multirow{3}{*}{$\begin{array}{l}\text { Mean } \\
\text { temper- } \\
\text { ature } \\
\left({ }^{\circ} \mathrm{F}\right)\end{array}$} & \multirow{3}{*}{$\begin{array}{c}\text { Mean } \\
\text { hamidi- } \\
\text { ty } \\
(\%)\end{array}$} \\
\hline & & \multicolumn{2}{|c|}{ Lot operated on } & \multicolumn{2}{|c|}{ Control } & & \\
\hline & & 3 & 9 & 3 & 9 & & \\
\hline $\begin{array}{l}\text { Fifth stage (from the com- } \\
\text { mencement of feeding to } \\
\text { the time of mounting) }\end{array}$ & $\underset{\mathrm{III}}{\mathrm{II}}$ & $\begin{array}{l}170.0 \\
171.0 \\
267.4\end{array}$ & $\begin{array}{l}175.7 \\
183.2 \\
278.0\end{array}$ & $\begin{array}{l}170.2 \\
173.1 \\
266.3\end{array}$ & $\begin{array}{l}171.7 \\
176.8 \\
294.5\end{array}$ & $\begin{array}{l}72.3 \\
72.3 \\
71.9\end{array}$ & $\begin{array}{l}95.0 \\
94.7 \\
65.9\end{array}$ \\
\hline $\begin{array}{l}\text { Pupal stage (from the time } \\
\text { of mounting to the time } \\
\text { of emergence) }\end{array}$ & $\underset{\text { III }}{\text { II }}$ & $\begin{array}{l}379.6 \\
435.8 \\
528.9\end{array}$ & $\begin{array}{l}393.1 \\
465.2 \\
466.3\end{array}$ & $\begin{array}{l}377.0 \\
424.1 \\
492.8\end{array}$ & $\begin{array}{l}368.3 \\
434.9 \\
463.4\end{array}$ & $\begin{array}{l}70.5 \\
70.3 \\
68.7\end{array}$ & $\begin{array}{l}98.2 \\
87.4 \\
60.8\end{array}$ \\
\hline $\begin{array}{l}\text { Adult stage (from the time } \\
\text { of emergenge to the } \\
\text { death) }\end{array}$ & III & 486.3 & 554.1 & 392.0 & 436.2 & 68.7 & 70.1 \\
\hline
\end{tabular}

N. B. II, III Shi $103 \times$ Nichi 110, operated on at the beginning of the fourth larval stage; $\mathrm{V}$ Daikojyo, operated on at the beginning of the fifth larval stage.

siderable development of fat tissues, as has been demonstrated by Regen" in Gryllus campestris and by Prell' in Cosmotriche potatoria. The prolongation of the duration of stages is related in all probability to the accumulation of fat substance. According to the results determined by Soxhlet's method, the amount of crude fat permeated out by ether is as in the following table."

\begin{tabular}{c|c|c}
\hline \multirow{2}{*}{ Race } & \multicolumn{2}{|c}{ Amount of crude fat (gr.) } \\
\cline { 2 - 3 } & Female operated on & Control \\
\hline Kasuriko & 0.070 & 0.019 \\
Daikojyo & 0.065 & 0.025 \\
\hline
\end{tabular}

N. B. The number of individuals subject to examination is 10 each in the first column and 30 each in the second.

The effect of castration on some quantitative characters.

Comparing the weight of cocoon-layer, the body-weight of pupa and the percentage of cocoon-layer in the operated and normal individuals the following results were obtained.

1) Zool. Anz. Bd. 35 (1910).

2) Zool. Jahrb. Abt. allg. Zool. u. Phys. d. Tiere. Bd. 35 (1915).

3) I am very much indebted to Mr. Shindo for the determination of the amount of crude fat. 


\begin{tabular}{|c|c|c|c|c|c|}
\hline \multirow{2}{*}{ Quantitative character } & \multirow{2}{*}{ Race } & \multicolumn{2}{|c|}{ Lot operated on } & \multicolumn{2}{|c|}{ Control } \\
\hline & & 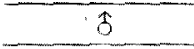 & 9 & $\delta$ & 9 \\
\hline \multirow[b]{2}{*}{ Weight of cocoon-layer (mg.) } & Showa & $124.60+3.31$ & $102.55 \pm 2.22$ & $111.87 \pm 3.65$ & $94.48+2.57$ \\
\hline & $\begin{array}{l}\text { Shimpaku } \\
\stackrel{x}{\times} \\
\text { Nichi } 110\end{array}$ & $197.43 \pm 2.34$ & $186.33 \pm 3.95$ & $173.00 \pm 4.13$ & $170.83 \pm 4.07$ \\
\hline \multirow[b]{2}{*}{ Body-weight of pupa (mg.) } & Showa & $889.92 \pm 14.12$ & $981.07 \pm 12.34$ & $841.00 \pm 15.95$ & $955.76 \pm 16.24$ \\
\hline & $\begin{array}{l}\text { Shimpaku } \\
\times \\
\text { Nichi } 110\end{array}$ & $1,022.29 \pm 9.22$ & $1,233.54 \pm 16.02$ & $987.92 \pm 12.72$ & $1,212.60 \pm 14.64$ \\
\hline \multirow{2}{*}{$\begin{array}{l}\text { Percentage of cocoon-layer } \\
\left(\frac{\text { Weight of cocoon-layer }}{\text { Total weight of cacoon }} \times 100\right)\end{array}$} & Showa & 12.20 & 9.40 & 11.66 & 8.93 \\
\hline & $\begin{array}{l}\text { Shimpaku } \\
\times \\
\text { Nichi } 110\end{array}$ & 16.08 & 13.04 & 14.80 & 12.27 \\
\hline
\end{tabular}

As may be evident from this table, the lots operated on invariably surpass the control in the weight of cocoon-layer, the body-weight of pupa and the percentage of cocoon-layer. To my mind, the cause of this phenomenon seems to be ascribed to the paramount effect upon the silk-gland and other internal organs of some substances which are used for the development of the gonads.

The effect of castration on the internal sexual organs of the moth.

With regard to the effect of eastration on the vas deferens, Kopec $^{1)}$ points out the shortening of the duct in Lymantria dispar, while Prell ${ }^{2}$ puts on record the absence of any noticeable change in C. potatoria. So far as experiments go, the vas deferens is of varying lengths, according to individuals subject to operation. In one case it was found to surpass that of the normal individual to a large extent and to end bluntly at a point lateral to the dorsal vessel in the fifth abdominal segment, where the testis is expected. These varying lengths are in all probability dependent upon the remaining amount of tissue-bands annexed to the testis and giving rise to the vas deferens.

Further, castration was found to affect the accessory gland which is developed together with the seminal vesicle and ejaculatory duct from the Herold's organ lying on the ventral side of the eighth abdominal segment.

In Lymantria dispar operated on Kopec demonstrates the appear-

1) Arch. f. Entw.-Mech. d. Org. Bd. 33 (1912).

2) Zool. Jahrb. Abt. allg. Zool. u. Phys. d. Thiere. Bd. 35 (1915). 


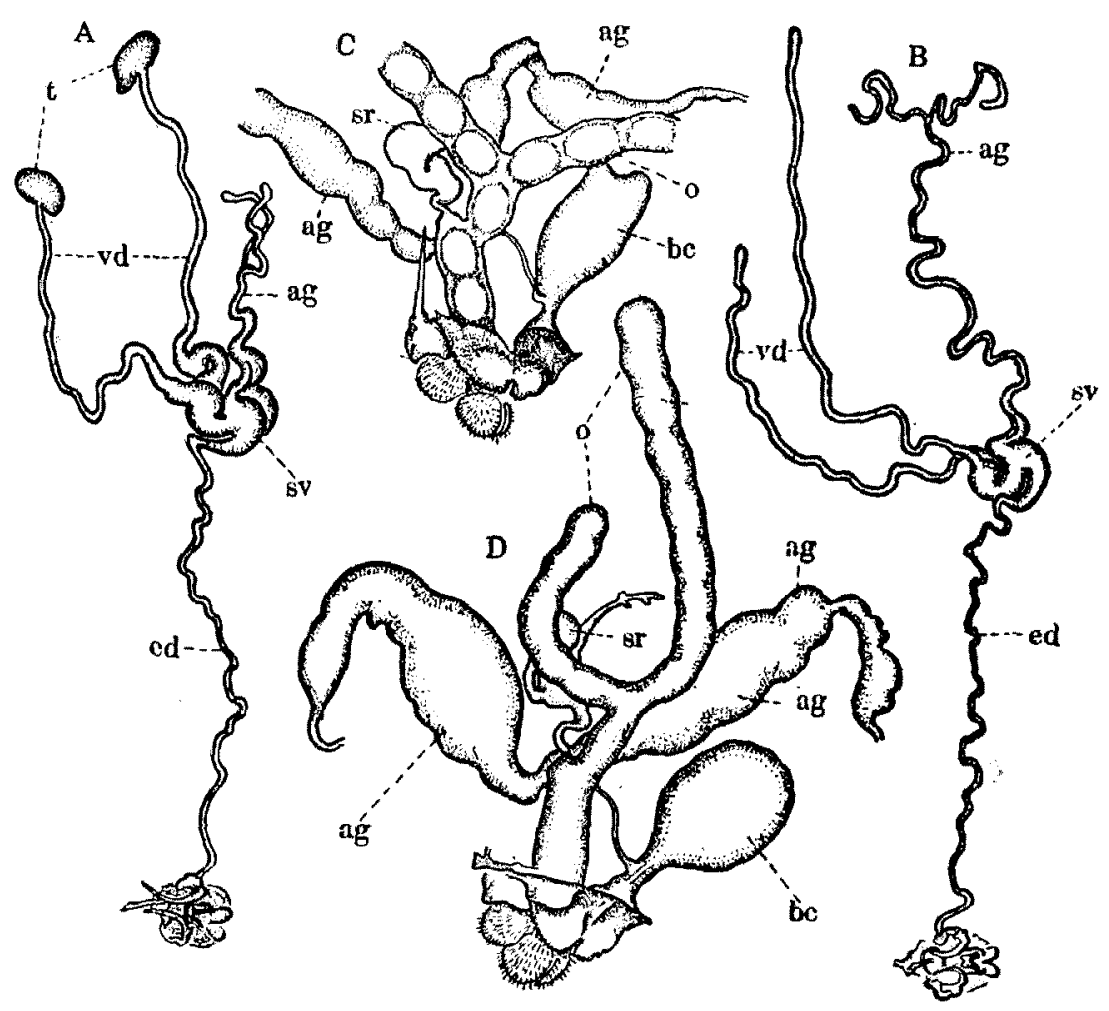

Internal sexual organs of the normal male moth (A), a male moth operated on (B), the normale female moth (C), and a female moth operated on (D).

ag accessory gland, bc bursa copulatrix, ed ejaculatory duct, o oviduct, sr seminal receptacle, $s v$ seminal vesicle, $t$ testis, vd vas deferens.

ance of moths which possess the paired oviducts of varying lengths or are entirely destitute of them. This similarity is also true of the silkworm moth. This state of things appears to me to be determined by the remaining amount of tissue-bands annexed to the ovary and giving rise to the oviduct.

Of other organs the accessory gland appears to enjoy the paramount effect of ovaritomy. In one case it was found to present the remarkable development of its reservoir and secretory portion. 